\title{
A case of self-healing collodion baby
}

\section{Przypadek samowyleczalnego zespołu dziecka kolodionowego}

\author{
Aleksandra Kitowska', Piotr Brzeziński',2, Justyna Słomka',2, Mieczysława Karcz', Józef Jasonek' \\ 'Dermatology Ward in Ustka, the District Tertiary Hospital in Slupsk, Poland \\ 2Department of Physiotherapy and Medical Emergency, Faculty of Health Sciences, Pomeranian Academy, Slupsk, Poland \\ 'Oddział Dermatologii w Ustce, Wojewódzki Szpital Specjalistyczny w Słupsku, Polska \\ ${ }^{2}$ Katedra Rehabilitacji i Odnowy Biologicznej, Instytut Nauk o Zdrowiu, Akademia Pomorska, Słupsk, Polska \\ Dermatol Rev/Przegl Dermatol 2021, 108, 38-45 \\ DOI: https://doi.org/l 0.5 I 14/dr.2021. 105892
}

\section{CORRESPONDING AUTHOR/} ADRES DO KORESPONDENCJI:

dr n. med. Piotr Brzeziński

Oddział Dermatologii w Ustce

Wojewódzki Szpital Specjalistyczny

w Słupsku

tel.: +4869211516

e-mail: brzezoo@wp.pl

\begin{abstract}
Introduction. Autosomal recessive congenital ichthyosis is a heterogeneous group of congenital disorders characterised by abnormal keratinisation and exfoliation of the epidermis. Some patients with this condition are born encased in collodion membrane.
\end{abstract}

Objective. The case of the autosomal recessive congenital ichthyosis subtype, a self-healing collodion baby, which is an uncommon phenotype of this disorder, accounting for approximately $10 \%$ of patients, is described.

Case report. A 3-day-old newborn showed features of a collodion baby at birth. Physical examination revealed diffuse yellow-wax skin lesions of a scale-like character on the skin of the whole body with numerous cracks of the stratum corneum, upper and lower eyelids eversion, lip curl, deformation of the auricles, and subtle flattening of the nose. Skin changes gradually disappeared starting from the $5^{\text {th }}$ day of life.

Conclusions. This rare case of the autosomal recessive congenital ichthyosis subtype, despite a significant regression of skin lesions, requires constant observation and dermatological supervision. There is a high probability that symptoms of ichthyosis of variable intensity will remain permanently.

\section{STRESZCZENIE}

Wprowadzenie. Autosomalna recesywna wrodzona rybia łuska jest niejednorodną grupą wrodzonych zaburzeń charakteryzujących się nieprawidłowym rogowaceniem i złuszczaniem naskórka. Część pacjentów w tym stanie rodzi się zamknięta w błonie kolodionowej.

Cel pracy. Opisujemy przypadek podtypu ARCI - samowyleczalny zespół dziecka kolodionowego (self-healing collodion baby), który jest fenotypem tego zaburzenia, występującym u około $10 \%$ pacjentów.

Opis przypadku. Noworodek przy urodzeniu wykazywał cechy dziecka kolodionowego. W 3. dniu życia, w badaniu przedmiotowym, stwierdzono rozlane zmiany skórne barwy żółtowoskowej w postaci łuski na skórze całego ciała z licznymi pęknięciami warstwy rogowej naskórka, wywinięcie powiek górnych i dolnych, wywinięcie warg, zniekształcenie małżowin usznych oraz subtelne spłaszczenie nosa. Zmiany skórne ustępowały stopniowo od 5. doby. 
Wnioski. Pomimo znacznego ustąpienia zmian skórnych ten przypadek rzadkiego podtypu autosomalnej recesywnej wrodzonej rybiej łuski wymaga stałej obserwacji i kontroli dermatologicznej. Istnieje duże prawdopodobieństwo, że mogą pozostać trwałe objawy rybiej łuski o różnym nasileniu.

Key words: ichthyosis, autosomal recessive congenital ichthyosis, lamellar ichthyosis, collodion baby.

Słowa kluczowe: rybia łuska, autosomalna recesywna wrodzona rybia łuska, rybia łuska blaszkowata, dziecko kolodionowe.

\section{INTRODUCTION}

Ichthyosis and erythrokeratoderma are keratinisation disorders in which abnormal differentiation and exfoliation of the epidermis leads to a defective epidermal barrier. Ichthyosis represents a large clinically and aetiologically heterogeneous group of diseases with generalised skin exfoliation. There are congenital and acquired forms of the disease. Congenital forms include lamellar ichthyosis, non-bullous congenital ichthyosiform erythroderma, and Harlequin ichthyosis; acquired forms include ichthyosis vulgaris and X-linked ichthyosis [1-3].

Autosomal recessive congenital ichthyosis (ARCI) includes several forms of ichthyosis.

Although the majority of newborns with ARCI are collodion babies, clinical presentation and severity of ARCI can vary significantly, ranging from harlequin ichthyosis, the most severe and often fatal form, to lamellar ichthyosis and non-bullous congenital ichthyosis $[2,4]$.

The presentation of the newborn baby covered by a transparent cellophane membrane is characteristic of a "collodion baby". Patients with this condition are born encased in the collodion membrane. The membrane usually detaches in the first 2-4 weeks, giving way to the primary disease.

In addition to these major forms of atypical ichthyosis, several rare subtypes have been identified, such as bathing ichthyosis, self-healing collodion ichthyosis, or ichthyosis-prematurity syndrome [1].

Management of newborns includes aseptic measures, adequate ambient humidity in the incubator, maintenance of electrolyte balance (risk of hypernatraemic dehydration), identification of early signs and/ or symptoms of infection, ophthalmic monitoring and care (risk of keratitis and corneal ulceration), use of emollients, daily bathing with moisturising and antiseptic agents, and the use of prophylactic local antibiotics at crack sites $[2,5]$.

\section{WPROWADZENIE}

Rybia łuska i erytrokeratodermie są zaburzeniami rogowacenia, w których nieprawidłowe różnicowanie i złuszczanie naskórka powoduje uszkodzenie bariery naskórkowej. Ichtiozy stanowią dużą, klinicznie i etiologicznie niejednorodną grupę stanów chorobowych z uogólnionym złuszczaniem się skóry. Istnieją wrodzone i nabyte formy tej choroby. Wrodzone postacie obejmują lamellar ichthyosis, non-bullous congenital ichthyosiform erythroderma i Harlequin ichthyosis; nabyte formy to ichthyosis vulgaris i X-linked ichthyosis [1-3].

Autosomalna recesywna wrodzona rybia łuska (autosomal recessive congenital ichthyosis - ARCI) obejmuje kilka form tej choroby.

Mimo że większość noworodków z ARCI to niemowlęta kolodionowe, obraz kliniczny i nasilenie ARCI mogą się znacznie różnić - od rybiej łuski arlekinowej, najcięższej i często śmiertelnej postaci, do rybiej łuski blaszkowatej i niepęcherzowej wrodzonej erytrodermii ichtiotycznej $[2,4]$.

Dziecko kolodionowe wyróżnia przezroczysta błona występująca w okresie noworodkowym. Pacjenci w tym stanie rodzą się „zamknięci” w błonie kolodionowej. Błona zwykle odrywa się w pierwszych 2-4 tygodniach, ustępując miejsca pierwotnej chorobie.

Oprócz głównych form nietypowej rybiej łuski rozpoznano kilka rzadszych podtypów, takich jak rybia łuska kąpielowa, samolecząca się rybia łuska kolodionowa i zespół rybia łuska-wcześniactwo [1].

$\mathrm{W}$ postępowaniu z noworodkami z rybią łuską należy stosować środki aseptyczne, dbać o odpowiednią wilgotność w inkubatorze, utrzymywać równowagę elektrolitów (ryzyko odwodnienia hipernatremicznego), obserwować wczesne objawy infekcji, zapewnić opiekę okulistyczną (ryzyko zapalenia rogówki i owrzodzenia rogówki), używać emolientów, wykonywać codzienne kąpiele ze środkami nawilżającymi i antyseptycznymi oraz w miejscach pęknięć profilaktycznie stosować antybiotyki $[2,5]$. 


\section{OBJECTIVE}

Described herein is the case of 1 form of lamellar ichthyosis, known as a self-healing collodion baby (SHCB) or a self-improving collodion ichthyosis (SICI), which is a less common phenotype of this disorder, accounting for approximately $10 \%$ of patients in whom the membrane peels off after a few weeks, leaving no hidden skin aberration.

\section{CASE REPORT}

A 3-day-old newborn girl from a twin diamniotic and dichorionic pregnancy (pregnancy 4, childbirth 4), born by natural labour in the $33^{\text {rd }}$ week of pregnancy, with weight at birth of $2140 \mathrm{~g}$ and body length $47 \mathrm{~cm}$, received 8 points on the Apgar scale. She was dermatologically consulted due to generalised skin changes. The child's mother reported a case of psoriasis in her cousin and a few cases of mild atopic dermatitis in the family. The family history is not otherwise burdened. The newborn's siblings are healthy. The course of pregnancy was uncomplicated, and the woman used only enoxaparin and folic acid during pregnancy. Laboratory tests performed in the gynaecology and obstetrics department revealed a reduced concentration of thyroid-stimulating hormone and vitamin $\mathrm{D}$. The mother of the newborn has never been diagnosed with thyroid diseases or other chronic diseases.

The physical examination of the girl revealed diffuse yellow-wax skin lesions of ichthyotic character on the skin of the whole body, with numerous cracks in the stratum corneum, upper and lower eyelid eversion, lip curl, deformation of auricles, and a subtle flattening of the nose (figs. $1 \mathrm{~A}, \mathrm{~B}$ ). There were no contractures in joints, positional flexion of limbs, or atrophy of the nails.

During hospitalisation, no difficulties with food intake were observed - the sucking reflex was good, the patient was bottle-fed, she ate willingly. Laboratory tests revealed anaemia and vitamin D deficiency. No other departures from the normal were found. Ultrasound examinations (of the central nervous system, lungs, and the abdominal cavity) were normal. No abnormalities were found in the ophthalmological examination performed on the $17^{\text {th }}$ day of life.

Recommendations involved application of a paraffin ointment every 2 hours on the affected skin in the initial period of treatment, then twice a day, as well as placing the newborn in an incubator with constant humidity and temperature, and increasing the supply of fluids and food to avoid malnutrition and dehydration.

Tolerance of the applied treatment was very good. Keratin plaque was completely exfoliated, revealing skin of moderate redness with persistent epidermis

\section{CEL PRACY}

W pracy opisano przypadek jednej z postaci rybiej łuski blaszkowatej, zwanej samowyleczalnym dzieckiem kolodionowym (self-healing collodion baby SHCB) lub samodoskonalącą się/samopoprawiającą się rybią łuską kolodionową (self-improving collodion ichthyosis - SICI). Jest to rzadki fenotyp tego zaburzenia, występujący u około $10 \%$ pacjentów, u których błona złuszcza się po kilku tygodniach, nie pozostawiając nieprawidłowości.

\section{OPIS PRZYPADKU}

Trzydniowy noworodek, dziewczynka, z ciąży bliźniaczej dwuowodniowej dwukosmówkowej (ciąża 4., poród 4.), urodzona siłami natury w 33. tygodniu ciąży, masa urodzeniowa 2140 g, długość ciała 47 cm, otrzymała 8 punktów w skali Apgar. Konsultowana dermatologicznie z powodu uogólnionych zmian skórnych. Z wywiadu od matki - w rodzinie występuje łuszczyca u kuzynki oraz nieliczne przypadki atopowego zapalenia skóry o lekkim nasileniu, poza tym wywiad rodzinny nieobciążony, rodzeństwo noworodka zdrowe. Ciąża przebiegała prawidłowo. Kobieta w trakcie ciąży stosowała jedynie enoksaparynę i kwas foliowy. W badaniach laboratoryjnych wykonanych na oddziale ginekologiczno-położniczym stwierdzono zmniejszone stężenie hormonu tyreotropowego oraz witaminy D. U matki nigdy nie zdiagnozowano chorób tarczycy i innych schorzeń przewlekłych.

$\mathrm{W}$ badaniu przedmiotowym $\mathrm{u}$ dziewczynki stwierdzono rozlane zmiany skórne barwy żółtowoskowej w postaci łuski na całej skórze z licznymi pęknięciami warstwy rogowej naskórka, wywinięcie powiek górnych i dolnych, wywinięcie warg, zniekształcenie małżowin usznych oraz subtelne spłaszczenie nosa (ryc. 1 A, B). Nie stwierdzono przykurczów w stawach, zgięcia ułożeniowego kończyn oraz zaników płytek paznokciowych.

$W$ trakcie hospitalizacji nie zaobserwowano trudności z przyjmowaniem pokarmu - odruch ssania dobry, dziecko karmione przez butelkę, chętnie jadło. $W$ badaniach laboratoryjnych - niedokrwistość oraz niedobór witaminy $\mathrm{D}$, poza tym nie stwierdzono odchyleń od normy. Badania ultrasonograficzne ośrodkowego układu nerwowego, płuc oraz jamy brzusznej były prawidłowe. W badaniu okulistycznym wykonanym w 17. dobie życia nie stwierdzono nieprawidłowości.

Zalecono stosowanie maści parafinowej co 2 godziny na skórę zmienioną chorobowo w początkowym okresie leczenia, następnie 2 razy dziennie, a także umieszczenie noworodka w inkubatorze 

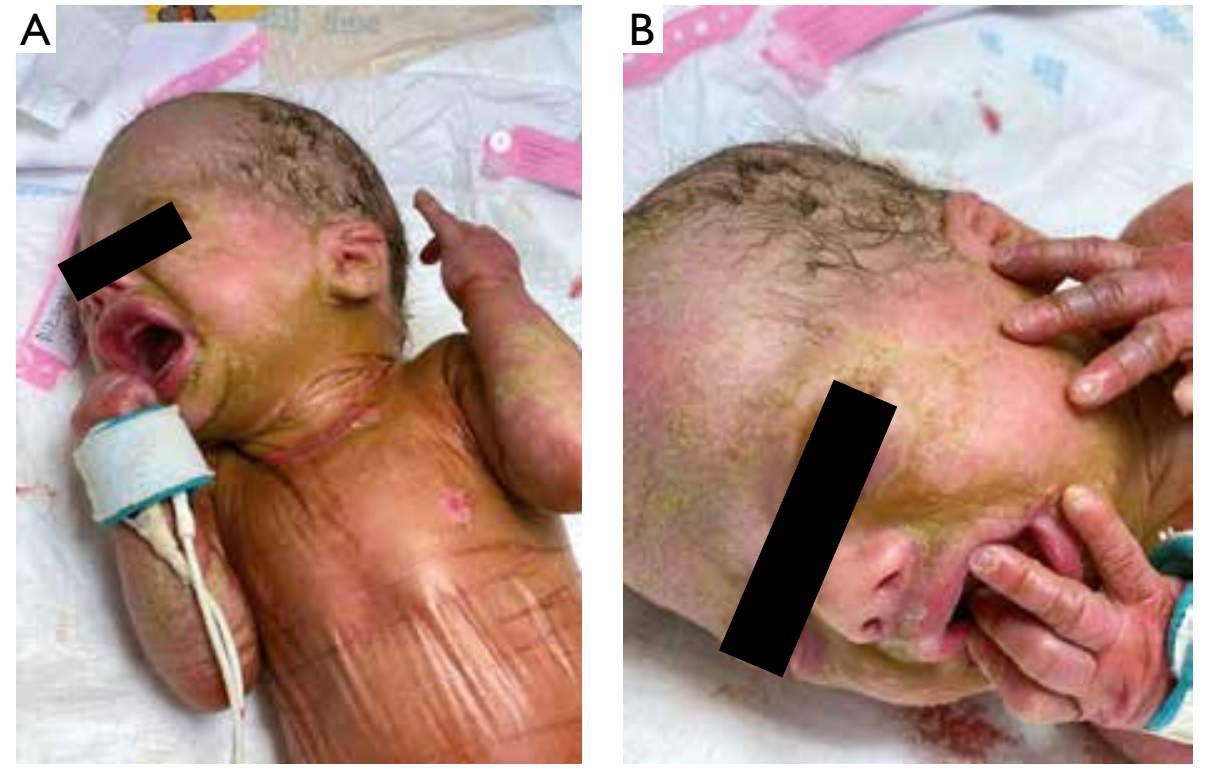

Figure I A, B. The patient on the $\left.\right|^{\text {st }}$ day after birth

Rycina I A, B. Pacjentka w I. dobie po narodzinach
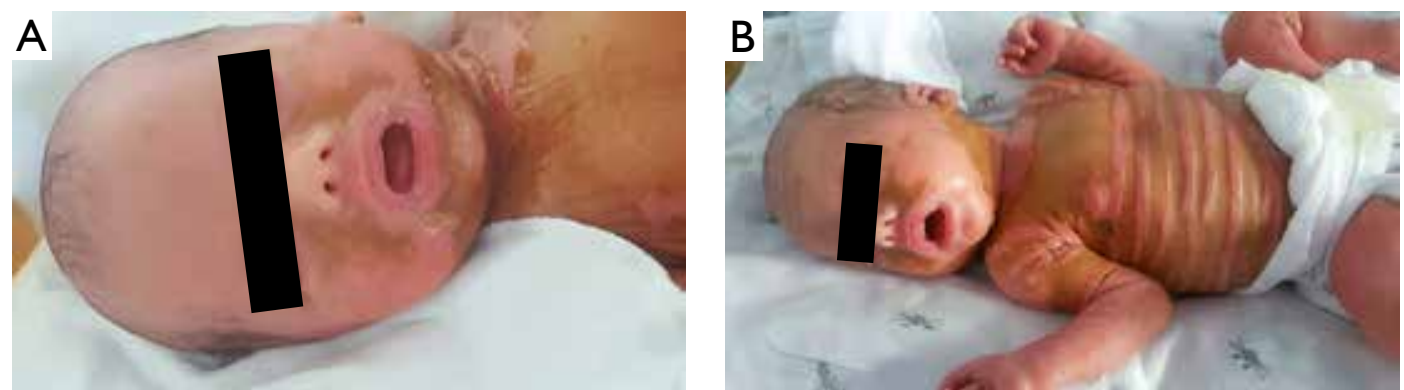

Figure $2 \mathrm{~A}, \mathrm{~B}$. The patient on the $5^{\text {th }}$ day after birth

Rycina 2 A, B. Pacjentka w 5. dobie po narodzinach

exfoliation, but of much lower intensity compared to the state before the treatment (figs. 2 A, B). Due to the girl's willingness to eat, observed from the first day of life (weight gain was observed, the girl ate whole portions), and very good effects of local treatment, the use of oral retinoids was abandoned.

On the $17^{\text {th }}$ day, the child was discharged in good general condition (figs. $3 \mathrm{~A}, \mathrm{~B}$ ) with further recommendations for intensive skin moisturizsing and lubricating, vitamin D supplementation, and staying under a constant supervision of the dermatological clinic.

\section{DISCUSSION}

The term ichthyosis comes from the Greek word "ichthys", which means "fish" and refers to the appearance of the skin resembling fish scales. Early reports of ichthyosis in Indian and Chinese literature date several hundred years back. Ichthyoses are part of a large, clinically and etiologically heterogeneous o stałej wilgotności i temperaturze oraz zwiększenie podaży płynów i pokarmów, aby uniknąć niedożywienia i odwodnienia.

Zastosowane leczenie było bardzo dobrze tolerowane. Płytki rogowe uległy całkowitemu złuszczeniu, odsłaniając skórę o umiarkowanym zaczerwienieniu z utrzymującym się złuszczaniem naskórka, jednak o znacznie mniejszym nasileniu w porównaniu ze stanem przed leczeniem (ryc. 2 A, B). Ze względu na chętne spożywanie posiłków od pierwszej doby życia (zaobserwowano zwiększenie masy ciała, dziewczynka zjadała całe porcje) i bardzo dobre efekty leczenia miejscowego odstąpiono od stosowania doustnych retinoidów.

W 17. dobie dziecko wypisano w stanie ogólnym dobrym (ryc. 3 A, B) z zaleceniami intensywnego nawilżania i natłuszczania skóry, suplementacji witaminą D oraz stałej opieki poradni dermatologicznej.

\section{OMÓWIENIE}

Termin rybia łuska pochodzi od greckiego słowa ichthys (ryba) i odnosi się do podobieństwa wyglądu 


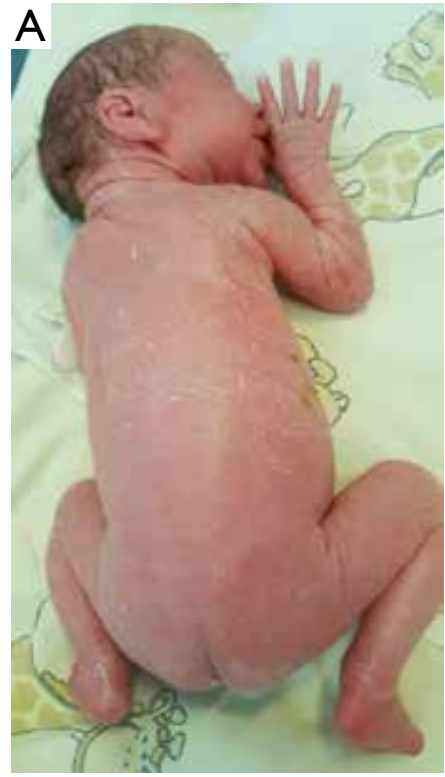

Figure 3 A, B. The patient on the 17th day after birth

Rycina 3 A, B. Pacjentka w 17. dobie po narodzinach

group of keratinisation disorders and usually cover the entire or most of the skin $[1,6]$.

Hallopeau and Watelet were the first to use the term "collodion baby". The skin of the newborn is replaced by a keratinised substance that gives the body an appearance of parchment or varnish. The condition is inherited primarily as autosomal recessive ichthyosis, lamellar ichthyosis, or non-blistering congenital ichthyosis. Collodion baby is an extremely rare dermatological disorder with an estimated frequency of 1 in 50,000 to 100,000 deliveries [4, 7]. Collodion babies are born with a tight, shiny coating. The skin is taut, shiny, translucent, or covered with an opaque membrane that surrounds the entire body and lasts for days or weeks. Most patients show the features of autosomal recessive congenital ichthyosis later in life, and in $10 \%$ of cases the skin eventually becomes normal or only minimally pathologically altered. This phenotype is called collodion self-healing baby (SHCB) or self-improving collodion ichthyosis (SICI), and is considered a subtype of ARCI. This classification of congenital ichthyosis was established in $2010[5,8]$. This defect was initially associated with mutations in the gene encoding keratinocyte transglutaminase type 1 (TGM1). TGM1 encodes the enzyme TGA-ase 1 - one of three TGA-ase enzymes found in the epidermis. This enzyme participates in the keratinous encasing. Patients with the TGM1 mutation lack the keratinised capsule, and the activity of TGAase 1 is reduced or absent $[9,10]$.

Besides the defect in the TGM1 coding gene, over 110 other mutations were reported, including ABCA12, ALOX12B, ALOXE3, CASP14, CERS3,

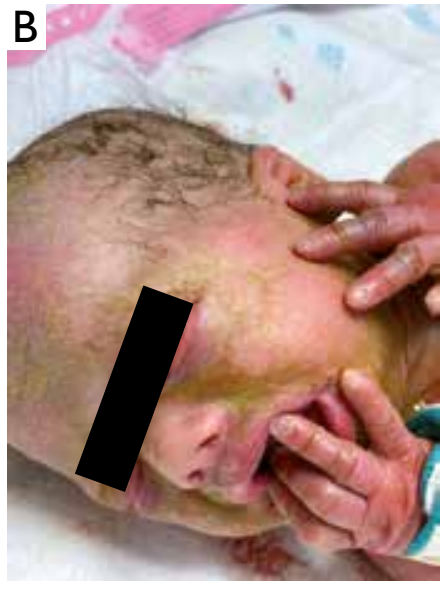

skóry do łusek ryb. Doniesienia o rybiej łusce znane są w literaturze indyjskiej i chińskiej od kilkuset lat. Ichtiozy stanowią część dużej, klinicznie i etiologicznie niejednorodnej grupy zaburzeń rogowacenia i zazwyczaj obejmują całą lub większą część skóry $[1,6]$.

Hallopeau i Watelet sformułowali termin collodion baby. Skórę noworodka zastępuje zrogowaciała substancja, która nadaje ciału wygląd pergaminowy lub lakierowany. Stan ten jest dziedziczony przede wszystkim jako autosomalna recesywna rybia łuska, rybia łuska blaszkowata lub niepęcherzowa wrodzona erytrodermia ichtiotyczna. Collodion baby jest niezwykle rzadkim schorzeniem dermatologicznym, szacunkowo występuje 1 przypadek na 50000 do 100000 porodów [4, 7]. Dzieci kolodionowe rodzą się z ciasną, lśniącą powłoką. Skóra jest napięta, błyszcząca, półprzezroczysta lub pokryta nieprzezroczystą błoną, która otacza całe ciało i utrzymuje się kilka dni lub tygodni. W późniejszym życiu większość pacjentów wykazuje cechy autosomalnej recesywnej wrodzonej rybiej luski, a w 10\% przypadków skóra ostatecznie staje się normalna lub tylko w minimalnym stopniu jest objęta procesem chorobowym. Fenotyp zwany samoleczącym się dzieckiem kolodionowym (SHCB) lub samowyleczalny zespół dziecka kolodionowego (SICI), uważany jest za podtyp ARCI według klasyfikacji wrodzonej rybiej łuski powstałej w 2010 roku $[5,8]$. Defekt ten początkowo wiązano z mutacjami w genie kodującym transglutaminazę keratynocytową typu 1 (TGM1). TGM1 koduje enzym TGazę-1, który jest jednym $z$ trzech enzymów TGA występujących w naskórku. Występuje ona w kopercie rogowej. U pacjentów z mutacją TGM1 brakuje zrogowaciałej 
CYP4F22, LIPN, NIPAL4, PNPLA1, SDR9C7, and SLC27A4 $[1,5,11]$.

In the Scandinavian study, DNA sequencing in 11 Swedish and 4 Danish SICI patients showed ALOX12B mutations in 8 cases, ALOXE3 mutations in 3 cases, and TGM1 mutations in 1 case [11]. In all cases, just like in the case reported here, spontaneous shedding of the collodion membrane occurred 2-4 weeks after birth. On the other hand, when these patients were re-examined at the age of 2-37 years, they showed keratosis, mild or focal exfoliation, palmar hyperlinearity with keratosis, and frequent appearance of red cheeks associated with follicular keratosis.

Due to impaired skin integrity, the most significant problems these infants are exposed to are hyperthermia, increased fluid loss and electrolyte disturbances, and skin infections. Breathing may also be difficult.

Clinically, most of the patients have large, dark brown, tightly attached scales on the scalp, limbs, and abdomen, but other areas may also be affected. In severely affected patients, thick rigid scales are periodically shed, causing deep painful fissures, especially around bends and on fingers, hands, and soles. Other features include restrictions in joint movements, contractures, keratosis of hands and feet, scarring alopecia and persistent ectropia, congenital hypoplasia of the nasal and auditory cartilage, and impaired sweating. The child's growth and intellect are normal. Severe forms of ichthyosis rarely disappear with age, and mental problems resulting from cosmetic effects and reduced mobility may lead to isolation or depression $[2,11,12]$.

Treatment includes emollients, keratolytic agents, topical calcipotriol, 10\% urea, and topical tazarotene $0.05 \%$ gel. In severe cases, acitretin $0.5-0.75 \mathrm{mg} / \mathrm{kg}$ bw/day may be used [4, 13]. Oral retinoids have a keratolytic effect that helps eliminate scales and prevents hyperkeratosis. However, in the reported case, we did not see the need to introduce a systemic therapy, and the good condition of the child was achieved using topical treatment only $[13,14]$.

As a result of the therapy, our patient started to improve on the 5 th day of hospitalisation. On the $3^{\text {rd }}$ day, the child was covered with the collodion membrane, limiting her movement. On the $12^{\text {th }}$ day, a moderate redness was noted with persistent exfoliation of the epidermis.

The course of disease was similar in the case described by the authors from Vietnam [15]. On day 30 , the skin was devoid of keratinised areas, but at 4 months of age, keratinisation of the skin of the back appeared. otoczki, a aktywność TGazy 1 jest zmniejszona lub nieobecna $[9,10]$.

Poza defektem w genie kodującym TGM1 zgłoszono ponad 110 innych mutacji, które obejmuja ABCA12, ALOX12B, ALOXE3, CASP14, CERS3, CYP4F22, LIPN, NIPAL4, PNPLA1, SDR9C7 i SLC27A4 $[1,5,11]$.

W badaniu skandynawskim sekwencjonowanie DNA u 11 szwedzkich i 4 duńskich pacjentów z SICI wykazało mutacje ALOX12B w 8 przypadkach, mutacje ALOXE3 w 3 przypadkach i mutacje TGM1 w 1 przypadku [11]. U wszystkich tych pacjentów, podobnie jak u opisywanego przez nas dziecka, spontaniczne zrzucenie kolodium nastąpiło po 2-4 tygodniach od urodzenia. Natomiast po ponownym zbadaniu tych pacjentów $\mathrm{w}$ wieku 2-37 lat stwierdzono rogowacenie skóry, łagodne lub ogniskowe złuszczanie, hiperlinearność dłoniową z rogowaceniem skóry, a także częste występowanie na skórze policzków rumienia i rogowacenia mieszkowego.

Z powodu naruszenia integralności skóry najistotniejszymi problemami są hipertermia, zwiększona utrata płynów, zaburzenia elektrolitowe i infekcje skóry. Utrudnione może być również oddychanie.

Klinicznie u pacjentów występują typowo duże, ciemnobrązowe, mocno przylegające łuski na skórze głowy, kończyn i brzucha, ale zmiany mogą dotyczyć również innych lokalizacji. W ciężkich przypadkach grube, sztywne łuski są okresowo zrzucane, co powoduje powstawanie głębokich, bolesnych szczelin, szczególnie wokół zgięć oraz na palcach, dłoniach i podeszwach. Inne cechy to ograniczenie ruchu stawów, przykurcze, rogowacenie dłoni i stóp, bliznowaciejące łysienie, uporczywa ektropia, wrodzona hipoplazja chrząstki nosowej i słuchowej oraz zburzone wydzielanie potu. Dzieci mają normalny wzrost i intelektualnie rozwijają się prawidłowo. Ciężkie formy rybiej łuski rzadko ustępują wraz z wiekiem, a problemy psychiczne wynikające $z$ defektów kosmetycznych i ograniczonej mobilności mogą prowadzić do izolacji lub depresji $[2,11,12]$.

Leczenie obejmuje stosowanie emolientów, środków keratolitycznych, miejscowo kalcypotriolu, $10 \%$ mocznika, miejscowo tazarotenu (0,05\% żel). W ciężkich przypadkach należy podawać acytretynę 0,5-0,75 mg/kg m.c./dobę [4,13]. Doustne retinoidy mają działanie keratolityczne, pomagają usuwać łuski i zapobiegają nadmiernemu rogowaceniu. $W$ opisanym przypadku nie było jednak potrzeby wprowadzania terapii ogólnej, a dobry stan dziecka uzyskano, stosując leczenie miejscowe [13, 14].

$\mathrm{U}$ opisanej pacjentki po zastosowaniu terapii poprawa nastąpiła już w 5. dobie hospitalizacji. W 3. dobie dziecko pokrywała błona kolodionowa, ograniczając jego ruchy. U opisanej pacjentki po zastosowaniu te- 
In the report of Noguera-Morel et al., in a girl, the collodion membrane completely disappeared within 3 weeks, leaving a diffuse, focal ichthyotic erythroderma [5]. At 6 months of age, only minimal facial erythema, very mild exfoliation in the armpit area, and hyperlinearity of the hands and soles remained. Mild features of ichthyosis persisted at the age of 4 years.

Analysing reported cases of SICI, Vahlquist showed that various types of symptoms of variable severity may persist throughout the lives of the patients: skin keratosis, focal exfoliation, palmar-plantar hyperlinearity, and red cheeks [16]. In addition, anhydrosis and heat intolerance were reported by the majority of patients.

\section{CONCLUSIONS}

The described case of a rare subtype of autosomal recessive congenital ichthyosis, a self-healing collodion child, is observed in approximately $10 \%$ of children with ARCI. The likelihood of almost complete resolution of ichthyosis symptoms in infancy is high. At a later age, however, the skin may show signs of dryness and mild exfoliation, palmar hyperlinearity, keratinisation of cheeks, and anhydrosis. Therefore, those patients should be monitored, and a dermatological history should be kept in order to improve the quality of their functioning.

\section{CONFLICT OF INTEREST}

The authors declare no conflict of interest. rapii poprawa nastąpiła już w 5. dobie hospitalizacji. W 12. dobie pojawiło się umiarkowane zaczerwienienie z utrzymującym się złuszczaniem naskórka.

Podobnie przebiegał proces chorobowy w przypadku opisanym przez autorów z Wietnamu [15]. W 30. dobie skóra była pozbawiona zrogowaciałych miejsc, jednak w 4. miesiącu życia pojawiło się rogowacenie skóry pleców.

W pracy Noguera-Morel i wsp. błona kolodionowa u dziewczynki spełzła całkowicie w czasie 3 tygodni, pozostawiając erytrodermię ichtiotyczną [5]. $\mathrm{W}$ wieku 6 miesięcy pozostał jedynie minimalny rumień twarzy, bardzo łagodne złuszczanie okolic pach i hiperlinearność dłoni oraz podeszew. Znikome cechy rybiej łuski utrzymywały się jeszcze w wieku 4 lat.

Analizując dotychczas opisane przypadki SICI, Vahlquist wykazał, że przez całe życie u tych pacjentów mogą utrzymywać się różnie nasilone objawy: rogowacenie skóry, ogniskowe złuszczanie, hiperlinearność dłoniowo-podeszwowa, czerwone policzki [16]. Ponadto większość pacjentów zgłaszała anhydrozę i nietolerancję ciepła.

\section{WNIOSKI}

Opisano przypadek rzadkiego podtypu autosomalnej recesywnej wrodzonej rybiej łuski, czyli samowyleczalny zespół dziecka kolodionowego, stanowiącego około 10\% przypadków ARCI. Prawdopodobieństwo prawie całkowitego ustąpienia objawów rybiej łuski w wieku niemowlęcym jest wysokie. Skóra w późniejszym wieku może być sucha, mogą pojawić się miernie nasilone złuszczanie, hiperlinearne dłonie, rogowacenie policzków, anhydroza. Zaleca się obserwowanie takich pacjentów i objęcie ich opieką dermatologiczną w celu poprawy jakości ich funkcjonowania.

\section{KONFLIKT INTERESÓW}

Autorzy nie zgłaszają konfliktu interesów.

\section{References}

\section{Piśmiennictwo}

1. Gopal Anoop D.S., Samayam A., Bijina K.D.: Ichthyoses: case series. Our Dermatol Online 2018, 9, 190-193.

2. Srinivasan S.M.: Expecting the most unexpected - a harlequin baby! A case report and literature analysis. Our Dermatol Online 2012, 3, 321-325.

3. Álvarez-Álvarez A., Rodríguez-Díaz E., Beteta-Gorriti V.: Collodion baby: A case of lamellar ichthyosis. An Pediatr (Barc) 2021, 94, 55-56.

4. Thakur V., Malhotra P., Lad D., Chatterjee D., Vinay K., Dogra S.: Ponatinib-induced lamellar ichthyosis-like eruption. Int J Dermatol 2020, 59, e156-e157.

5. Noguera-Morel L., Feito-Rodríguez M., Maldonado-Cid P., García-Miñáur S., Kamsteeg E.J., González-Sarmiento R., et al.: Two cases of autosomal recessive congenital ichthyosis due to CYP4F22 mutations: expanding the genotype of self-healing collodion baby. Pediatr Dermatol 2016, 33, e48-e51.

6. Esperón-Moldes U., Ginarte-Val M., Rodríguez-Pazos L., Fachal L., Martín-Santiago A., Vicente A., et al.: Novel CYP4F22 mutations associated with autosomal recessive congenital ichthyosis (ARCI). Study of the CYP4F22 c.1303C $>$ T founder mutation. PLoS One 2020, 15, e0229025. 
7. Muñoz-Aceituno E., Nogera-Morel L., Torrelo A., Hernandez-Martin A.: Mild collodion baby as a presenting sign of loricrin keratoderma: report of a case and review of the literature. Clin Exp Dermatol 2020, 45, 395-398.

8. Oji V., Tadini G., Akiyama M., Blanchet Bardon C., Bodemer C., Bourrat E., et al.: Revised nomenclature and classification of inherited ichthyoses: results of the First Ichthyosis Consensus Conference in Sorèze 2009. J Am Acad Dermatol 2010, 63, 607-641.

9. Zhang H., Ericsson M., Weström S., Vahlquist A., Virtanen M., Törmä H.: Patients with congenital ichthyosis and TGM1 mutations overexpress other ARCI genes in the skin: part of a barrier repair response? Exp Dermatol 2019, 28, 1164-1171.

10. Abreu Velez A.M., Devaro J., Howard M.S.: A cutaneous rash with mixed gell coombs allergic features, sclerodermoid changes and status post previous therapy. Our Dermatol Online 2017, 8, 420-423.

11. Vahlquist A., Bygum A., Gånemo A., Virtanen M., Hellström-Pigg M., Strauss G., et al.: Genotypic and clinical spectrum of self-improving collodion ichthyosis: ALOX12B, ALOXE3, and TGM1 mutations in Scandinavian patients. J Invest Dermatol 2010, 130, 438-443.

12. Bourrat E., Blanchet-Bardon C., Derbois C., Cure S., Fischer J.: Specific TGM1 mutation profiles in bathing suit and self-improving collodion ichthyoses: phenotypic and genotypic data from 9 patients with dynamic phenotypes of autosomal recessive congenital ichthyosis. Arch Dermatol 2012, 148, 1191-1195.

13. Moraes E.L.L., Freire M.H.S., Rocha F., Secco I.L., Costa T., Afonso R.Q.: Nursing care for a newborn with lamellar ichthyosis: a case study in a neonatal unit. Rev Esc Enferm USP 2019; 53, e03519.

14. Achehb Bubna A., Veeraraghavan M., Anandan S., Rangarajan S.: A case of lamellar ichthyosis with rickets and carcinoma of the hypopharynx. Indian J Dermatol 2014, 59, 634.

15. Diep Q.M., Luong L.H., Tran T.H., Dinh O.T.L., Nguyen H.Q., Bui T.H., et al.: A case of self-improving collodion ichthyosis in Vietnam. Pediatr Dermatol 2020, 37, 574-575.

16. Vahlquist A.: Pleomorphic ichthyosis: proposed name for a heterogeneous group of congenital ichthyoses with phenotypic shifting and mild residual scaling. Acta Derm Venereol 2010, 90, 454-460.

Received: 12.05 .2020

Accepted: 14.08 .2020

Otrzymano: $12.05 .2020 \mathrm{r}$.

Zaakceptowano: $14.08 .2020 \mathrm{r}$

How to cite this article

Kitowska A., Brzeziński P., Słomka J., Karcz M., Jasonek J.: A case of self-healing collodion baby. Dermatol Rev/Przegl Dermatol 2021, 108, 38-45. DOI: https://doi.org/10.5114/dr.2021.105892. 